\title{
ON DIPTERA OF THE FAMILY EPHYDRIDAE.
}

\author{
JAMES S. HINE.
}

The literature on this family, so far as North American forms are concerned, is accessible to most students. In Monograph of N. A. Diptera, I862, I, I29-172, and in Zeitschr. f. d. Ges. Naturw., 1878, LI, I92-203, Loew gives the results of his studies. In Berliner Entom. Zeitschrift, I896, XII, 91-276, Becker fully treats the European species, and it is necessary to refer to this work for a consideration of the species common to the two countries. Williston has described a number of species in North American Fauna, r 893, VII, 257-258, and in Diptera of St. Vincent, I899, 389-404. The same author furnishes a contribution to the life history of one of the species and describes the adult of Ephydra californica Packard in Trans. Conn. Acad., 1883, VI, 83-86. Coquillett has published several papers in which new genera and species are described as follows: Ent. News, 1896, VII, 220; Can. Entom., I899, XXXI, 8 ; Diptera of Puerto Rico, 1900, 259-262; Can. Entom., I900, XXXII, 33-36; Diptera from the Harriman Alaska Expedition, I 900, 46I-462; Journal N. Y. Ent. Soc. I902, X, I 82-I84. Wheeler has reviewed the genus Octhera and described one new species in Ent. News, I 896, VII, I2I-I23. Howard has given a full account of Psilopa petrolei Coquillett, found breeding in crude petroleum in California, in Scientific American, I899, LXXX, 75-76.

One who collects Diptera in marshes or along streams is likely, sooner or later, to become interested in the numerous species of this family. Among the various water plants that grow in the marshes at Sandusky, one finds them plentiful, and some of the forms are the most numerous of all insects during at least a part of the summer. From a row-boat one can see them running over lily pads, wild rice and other foliage, but they are difficult to capture, since they are very active and fly away before the cyanide bottle can be placed over them, or if one uses a net he has to strike so low that it is almost impossible to prevent dipping it in the water, and by so doing spoil the specinens he succeeds in entrapping. After a little experience the collector is led to realize that the specimens ruuning over foliage are trifling with him. Better results may be obtained by collecting from flowers of water lilies. Locate one of these flowers and place the hand gently over its top in such a way as to entrap the flies that are feeding on its nectar; then without gripping tightly enough to crush the flower and with it the entrapped insects, pull it from its peduncle and drop into a wide-mouthed cyanide bottle prepared for the purpose. This is the most desirable method I have ever 
tried for procuring a supply of fine specimens of the small Diptera common in marshes.

The best of results. in collecting Ephydrids may be obtained by sweeping grasses in low ground in the vicinity of water, or along the margin of streams, but specimens procured in this way are apt to be teneral and not so desirable as those taken from flowers.

Dichafta Meigen.

There are three descriped North American species in this genus. Two of them, caudata and brevicauda, are distinguished from species of Notiphila by the uniform dark color of the body, but not so with furcata which has the abdomen distinctly bicolored. The males of all the species are characterized by the elongated bristles at the tip of the abdomen. The following key is offered for separating the species of the genus :

I. Abdomen uniformly dark, nearly black in color Abdomen bicolorous

2.

furcata Coq.

2. Last segment of male abdomen distinctly prolonged into a conical point

Last segment of male abdomen not noticeably prolonged

caudata Iallen.

brevicauda Loew.

\section{Notiphila Fallen.}

This genus is represented in Ohio by a number of species. N. unicolor Loew is probably the most abundant species of insect to be found at Sandusky during a part of the summer. The eggs of this species are deposited on various leaves over the water, and so abundant are they at times that large areas of wild rice and other plants are colored white by them. Oviposition seems to take place mostly in the evening and in egg-laying season the flies collect on the plants by thousands, so that one in a row-boat at dusk may see water plants almost entirely covered by them. The adults are most abundant in July. When the eggs hatch the larvae drop into the water and sink to the bottom.

Psilopa FUl.VIPENNIS n. $\mathrm{sp}$.

Shining black or violaceous. Antennea red, except the third segment, which is partially fuscus, thorax and abdomen deep shining black with a violaceous tinge, legs black with the exception of the knees, apexes of the tibiae, and the tarsi, which are red. Wings uniformly brownish yellow all over, knob of halteres yellow. Length slightly under 2.5 millimeters.

Habitat: Three specimens procured at Cameron, Louisiana, August 20. Taken by sweeping from grasses growing in low ground.

The uniform brownish yellow wings, together with the shining black thorax and abdomen characterize this species. 
Cannia R. D.

I. Wings fumid

2.

Wings grayish hyaline

2. Legs red, abdomen uniformly colored

Legs black, abdomen with greenish gray crossbands

3. Wings uniform grayish hyaline, knees of all the legs plainly red, abdomen green, segments three to five with a middorsal row of bronze triangles, length, 6 millimeters

Wings grayish hyaline with marginal cell dark gray, abdomen greenish with broad bases of last three segments violet bronze, length 4 millimeters

bisetosa Coquillett.

fumosa Stehn.

virida $\mathrm{n} . \mathrm{sp}$.

Caenia fumosa Sten.

This is a European species, and so far as I can find has not been reported from this country heretofore. The seven specimens before me, taken at Castalia, Obio, July i 3, r9or, agree so well with the description of fumosa given by Schiner, and are so readily traced to this species by Becker's key, that I do not hesitate to identify them as such.

- Caenia virida n. sp.

General color dark green, thinly yellowish and gray pruinose. Antennae clear brown, arista rather long pectinate above on inedian third, hairy on basal part, proboscis dark nearly black, face and cheeks rather densely yellowish pruinose except on upper part where the green ground color is distinct, clothed with rather short black hairs, bristles of the oral border distinct; front -green shining, with two pairs of orbital bristles, dorsum of thorax green, thinly yellowish pruinose and with five pairs of dorsocentral bristles, pruinosity of the pleura dense obscuring the ground color, scutellum green shining with two pairs of bristles, legs black except the knees which are narrowly but plainly red, wings uniformly grayish hyaline, veins brown, halteres yellow; abdomen shining green thinly gray pruinose, a middorsal row of bronze triangles on segments three to five and suggestions of bronze on the anterior margins of the sides of the same segments, two to four nearly equal in length, five much longer. Length 6 millimeters.

Habitat: Brownsville, Texas.

Several specimens collected by Charles Dury of Cincinnati in April and May, 1903. 